\title{
Examination of nutrient leaching dynamics of Solidago virgaurea in Hévíz Lake and Hévíz canal
}

\author{
Szabina Simon - Brigitta Simon - Angéla Anda \\ Hungarian University of Agriculture and Life Sciences, Georgikon Campus, P. O. Box 71 Keszthely, H-8361 Hungary \\ simonszabina95@gmail.com
}

\section{SUMMARY}

\begin{abstract}
The different nitrogen and phosphorus elements are prime constituents of the ecosystem and can exert a major effect on aquatic species and the overall ecological cycle. During our investigation we examined the nutrient leaching dynamics in decomposing leaf litter (stem and leaf blades) of Solidago virgaurea. We chose four different sampling sites during the winter period with different water temperatures in the Héviz Lake and Héviz canal. The bottles containing the plant material and water were incubated at natural temperatures and the fluid was removed at particular times. Water parameters such as pH level, conductivity, nutrients (ammonium and phosphates) were measured. In the case of Solidago leaf, we obtained higher values for all parameters compared to the stem ones.
\end{abstract}

Keywords: leaching; Solidago virgaurea; Lake Héviz; Hévíz canal

\section{INTRODUCTION}

Plant litter decomposition is highly complex involving several factors such as physical and chemical processes and the role of bacteria, fungi, and invertebrates in the breakdown. The physical and chemical characteristics of the plant material, environmental conditions such as temperature and the presence of humidity and nutrients are all determining factors on decomposition (Bärlocher et al., 2007). Leaf litter decomposition studies highlight the importance and implication of both inner (plant characteristics) and outside (environmental) factors (Gessner et al., 1997). Among chemical characteristics, the concentration of nutrients - such as nitrogen, compounds or lignin, cellulose and further plant components as polyphenols - exhibit the major influence. The inner characteristics also include the physical leaf properties as waxed conjunctive tissues and mainly leaf solidity. The hardness of plant tissues slows down the decomposing of terrestrial (Cornelissen et al., 1999), marine (Pennings and Paul, 1992) and fresh-water invertebrates (Arsuffi and Suberkropp, 1984).

Decomposition and photosynthesis are processes primarily responsible for the majority of biological carbon dioxide processing. Photosynthesis has been widely researched and studied at the biochemical and ecological levels. It must be noticed that decomposing factors transform nearly the same amount of carbon dioxide as photosynthesis. However, most of decomposition is mainly "invisible" and takes place with the help of fungi and bacteria. The biochemistry of such decomposition is immensely complex that can explain why it is a far less studied process. However, recent years have shown the elementary need for a deeper and more precise understanding of the process. The decomposition of organic substances is responsible for the immense amount of carbon dioxide released to the atmosphere, it is strongly connected to the nutrient cycle and it plays an inevitable role in the regeneration of organically bound substances (Berg and McClaugherty, 2008).
Decomposition is far more difficult to be determined than photosynthesis, it includes physical, chemical, and biological mechanisms which transform an organic substance to a more stable form (Berg and McClaugherty, 2008). Dissolution means the abiotic leaving of easily soluble compounds. After a plant material enters the water most of the dissolution takes places within the first 24-48 hours, and the plant material can even lose 30 percent of its original mass, depending on the particular species and environmental factors. The dynamics of the dissolution of chemical compounds differs in case of fresh or pre-dried leaf litter (Gessner, 1991), though no influence could be observed on the invertebrates' colonization (Gessner and Dobson, 1993). During dissolution it is primarily the carbohydrates and polyphenols which dissolve into water (Suberkropp and Klug, 1976). Previous studies have shown that certain constituents such as lignin and tannin can exert some effect on this process e.g.: they can slow it down (Suberkropp and Klug, 1976).

Changes in the quality and quantity of the compounds retained in leaf litter can influence the speed of decomposition with the selective stimulation or inhibition in the colonization of aquatic microorganisms (Bengtsson, 1992). Furthermore, they influence the dynamics of dissolved organic matter in water and their flocculation to solid particles (Bärlocher et al., 1989). In certain regions the time of leaf litter fall can coincide with the first night frosts sub-zero temperatures that can exert an effect on plant matter similar to drying as it can damage cell membranes which usually accelerate the process of dissolution (Bärlocher, 1992). In fresh water and coastal environments leaf litter acts as an abundant and important energy source for the aquatic food webs. Nitrogen and phosphor are the key chemical compounds in determining nutrient quality (Enriquez et al., 1993) mainly because of their role impacting the eutrophication processes of surface waters.

Invasive species suppress native species from their natural habitats and may even form a monoculture (Richardson, 2011). The goldenrod (Solidago 
virgaurea L.) is a member of the Holartic Solidago genus (Asteracea) which is made up of approximately one hundred species. Most of its species is native in North America and Eurasia, there are only six to ten, while in Hungary merely one (Solidago virgaurea) native specie (Semple and Cook, 2006). They can usually be found at the forest edges, roadsides and along riverbanks (Kolodziej et al., 2011). In Hungary, the goldenrod is constantly spreading along lakes and rivers so its spread can also be observed at Hévíz Lake and at the bank of the Hévíz canal.

A thorough examination and understanding of the natural background is essentialto maintain good water quality. In the winter period, an investigation was conducted to study the phosphor and ammonium dissolution dynamics for both the stem and leaf material of the goldenrod. We chose four different sampling sites, Lake Hévíz and three sites at the Hévíz canal with different water temperatures to determine the amount of phosphor and ammonium at these four sites dissolving into the water during the decomposition of the stem and leaf material of Solidago virgaurea.

\section{MATERIALS AND METHODS}

During our investigation the dissolution rate of nitrogen and phosphor compounds of the stem and leaf material of Solidago virgaurea was investigated using the percolation method of Pomogyi (1983). The examined plant material was collected in the autumn period, at the time of litter fall, then cleaned in laboratory and finally dried at room temperature $\left(24^{\circ} \mathrm{C}\right)$ until reaching constant dry weight. 10 grams of each plant material (stem and leaves) were weighed and placed in $500 \mathrm{ml}$ bottles - with three repetitions for each plant material - and filled with $450 \mathrm{ml}$ distilled water. The bottles containing the samples were incubated at natural temperature in Hévíz Lake and at three different sites with different water temperatures of the Hévíz canal. These sampling sites had different water temperatures; the farer the distance from Hévíz Lake, the lower the water temperature was. This arrangement simulated a natural water temperature gradient. The temperature gradient should be useful in planning mitigation of local impacts of global warming on natural habitats.

The samples were retrieved after 1, 2, 4, 7, 21, 42, 70,98 days after placing them into water. During each sampling, the liquid was removed and replaced with distilled water, and the bottles were placed back into the water.

The amount of ammonium and phosphate was measured using a Lovibond MultiDirect spectrophotometer while $\mathrm{PH}$ and conductivity were determined with applying a Neotek-Ponsel Odeon digital meter. Temporary correlation in dissolution of biogenic compounds into water will also be clearly demonstrated in the analysis using T-tests with a significance level of 5\% (Microsoft Office Excel 2016).

\section{RESULTS AND DISCUSSION}

The $\mathrm{pH}$ values of the water samples taken from the glasses are shown in Figure 1 (a) and (b). At the first day, $\mathrm{pH}$ of the water grew rapidly and reached the maximum ( $\mathrm{pH}=6.72$ and 6.56 ), followed by the gradual decrease in shoot parts. In case of stem, the $\mathrm{pH}$ reached a stable value, finally. The $\mathrm{pH}$ of leaves and stems did not differ significantly $(\mathrm{P}=0.0836-0.7458)$ during the investigated period. Regarding study sites there were no significant differences between them neither in case of leaves $(\mathrm{P}=0.1281-0.8359)$, nor stems $(\mathrm{P}=0.2808$ $0.8645)$.

Figure 1 (c) and (d) show the conductivity in the bottles. The high conductivity measured after the first sampling was followed by a sharp decrease on the second and third sampling days and showed an upward trend after the third day. As the conductivity was higher in the case of the leaf blades, the amount of dissolved nutrients in the leaf was also higher. The conductivity of leaves and stems did not differ significantly $(\mathrm{P}=0.0802-0.1885)$ in this study, except of $\mathrm{Hc} 2$ $(\mathrm{P}=0.0429)$. Regarding study sites there were no significant differences found neither in case of leaves $(\mathrm{P}=0.3777-0.9121)$, nor stems $(\mathrm{P}=0.4858-0.9502)$.

Dahrouga et al. (2016) examined the existence of temporal fluctuations of the limnological parameters during the decomposition of Eichhornia azuera. This study has showed the strong correlation in the conductivity of water density and bacterial biomass. According to Esteves (1988), conductivity values were related to the trophic state of the water. Thus, increased nutrient concentrations from the dissolution of ions could influence conductivity.

The rapid increase of ammonium concentration (Figure 2) at the beginning stage was mainly derived from rapid leaching, and the subsequent decrease was probably attributed to nitrification by nitrifying bacteria in the water. Significant differences were found between the ammonium concentrations of leaves and stems (LH: $\mathrm{P}<0.001, \mathrm{Hc} 1: \mathrm{P}=0.0015$, Hc2: $\mathrm{P}=0.0007$, Hc3: $\mathrm{P}=0.0007)$. Regarding study sites there were no significant differences found neither in case of leaves $(\mathrm{P}=0.2494-0.5609)$, nor stems $(\mathrm{P}=0.0543-0.8999)$.

$\mathrm{Wu}$ et al. (2017) showed the amount of plant material increments boosts the concentration of ammonium; for example, when the amount of Eichornia crassipes increased from 0.1 to $1.0 \mathrm{gr}$, the amount of ammonium in the water also rose from 2.58 to $14.30 \mathrm{mg} \mathrm{L}^{-1}$. Reddy and Sacco (1981) measured the decrease of ammonium in the incubated bottles following the first 14 days which they explained with the microbial activities during protein production by microbes and the evaporation of ammonium. Then, they observed the slow growth of the ammonium concentration. Tamire et al. (2017) reported about a similar tendency in the nitrate dissolution of Arundo donax, Echinochloa colona, Potamogeton schweinfurthii, Cyperus articulatus, Typha latifolia, Cyperus papyrus and Nymphaea lotus. 
Figure 1. Change in pH [Solidago leaves (a) and stem (b)] and conductivity $\left(\mu \mathrm{S} \mathrm{cm}^{-1}\right)$ [Solidago leaves (c) and stem (d)] in the incubated bottles during the experiment period in Lake Hévíz (LH), Hévíz canal 1 (He1), Hévíz canal 2 (He2) and Hévíz canal 3 (He3)
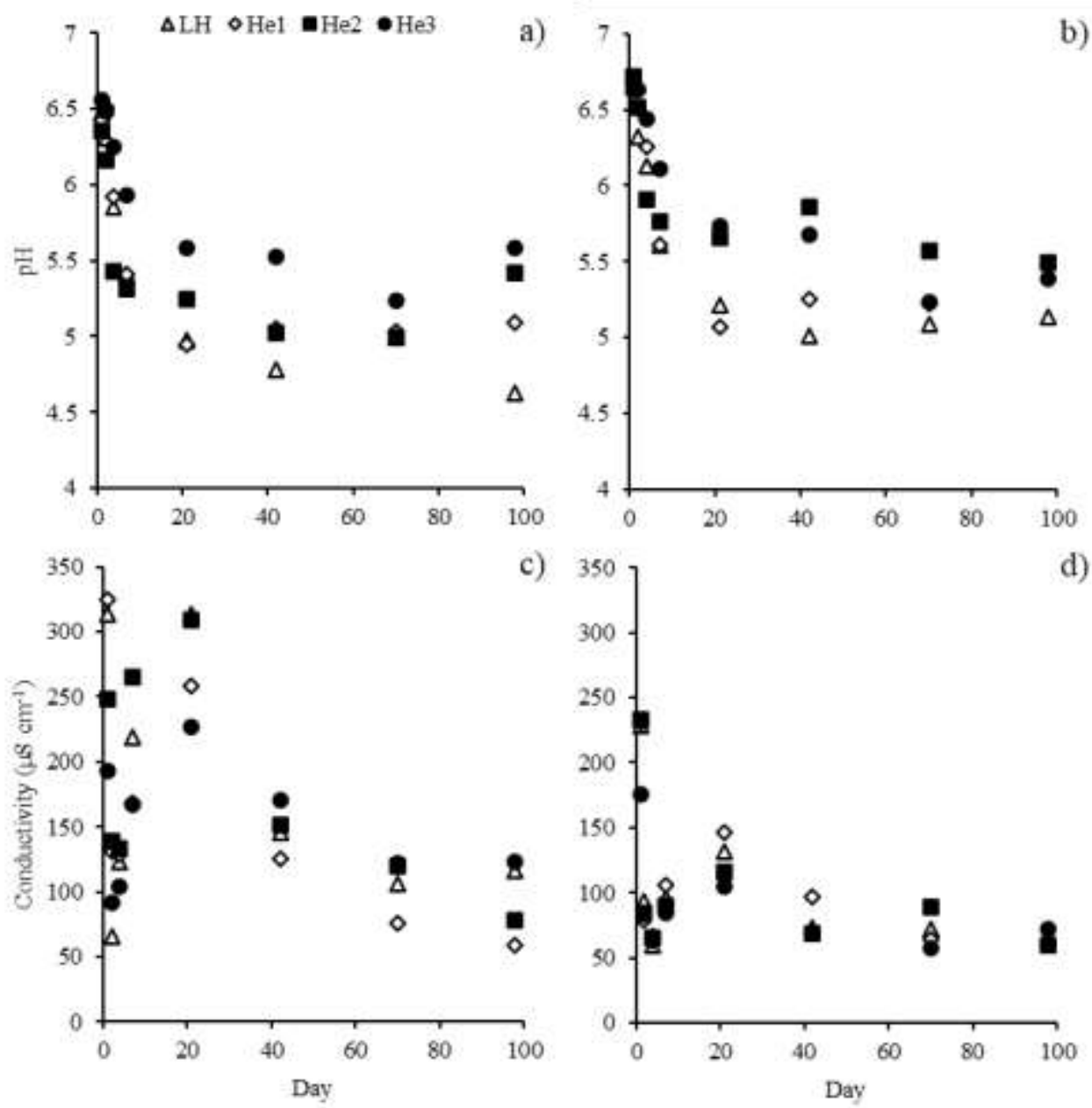

Figure 2. Change in ammonium concentrations $\left(\mathrm{mg} \mathrm{L}^{-1}\right)$ in the water of the incubated bottles in Lake Hévíz (LH), Hévíz canal 1 (He1), Hévíz canal 2 (He2) and Hévíz canal 3 (He3) in Solidago leaves (a) and stems (b)
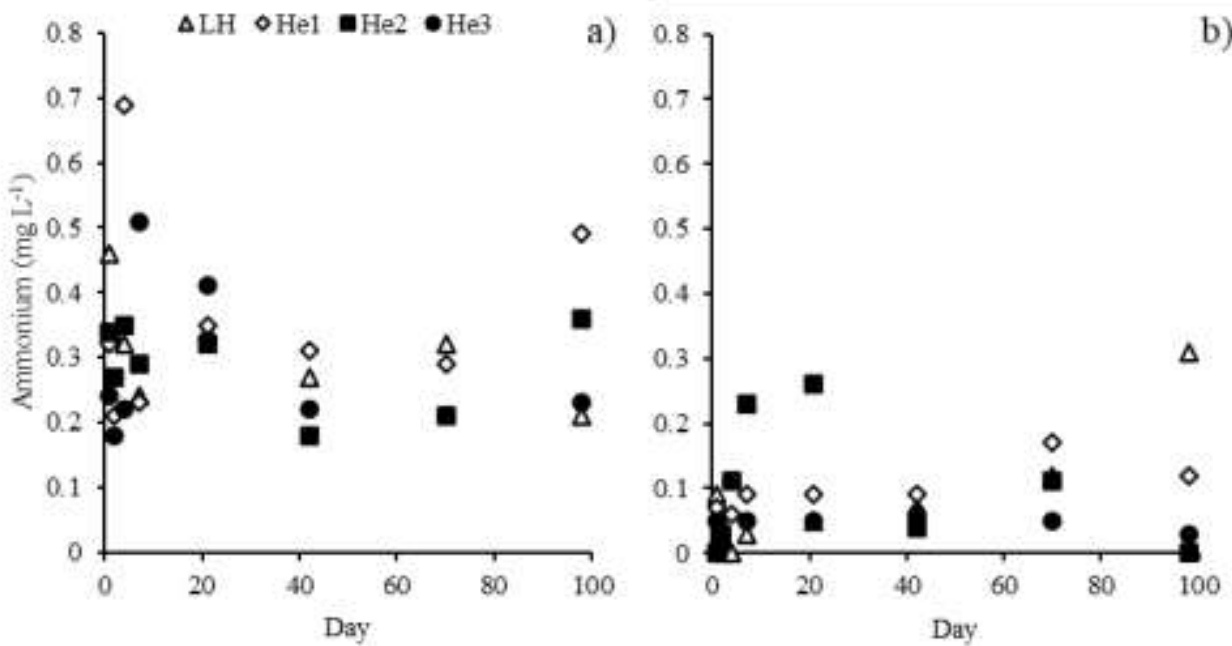
According to our results, the phosphorous concentration from the decomposition of the stems appears to be lower than values for the leaf blade [Figure 3 (b)] due to the quite different phosphate concentrations in leaf and stem. The rate of phosphorus leaching out of leaf blades decreased compared to stem. The highest concentrations were measured on the first sample days for both plant organs. The phosphate concentration of leaves and stems did not differ significantly $\quad(\mathrm{P}=0.0772-0.1836)$ during the investigated period. Regarding study sites there were no significant differences between them neither in case of leaves $(\mathrm{P}=0.6507-0.8849)$, nor stems $(\mathrm{P}=0.1318$ 0.9129).
Park and Cho (2003) reported that the phosphate of the aquatic macrofites can significantly contribute to the eutrophication of some aquatic ecosystems. Tamire et al. (2017) incubated 3 grams of Potamogeton shcweinfurthii macrofites in $1 \mathrm{~L}$ of water. They measured that the concentration of phosphate in Lake Ziway (Ethiopia) increased from $35 \mu \mathrm{g} \mathrm{L} \mathrm{L}^{-1}$ to 160 $\mu \mathrm{g} \mathrm{L}^{-1}$. There is a similarity between the study site of Gibtain and Abera (2012) in Ethiopia and our one, as River Bulbula is coming from Lake Ziway similarly to Hévíz canal and Lake Hévíz. They measured significantly higher phosphate concentration at the estuary of River Bulbula $\left(212 \mu \mathrm{g} \mathrm{L}^{-1}\right)$ than in Lake Ziway.

Figure 3. Change in phosphorous concentrations $\left(\mathrm{mg} \mathrm{L}^{-1}\right)$ in the water of the incubated bottles in Lake Hévíz (LH), Hévíz canal 1 (He1), Hévíz canal 2 (He2) and Hévíz canal 3 (He3) in Solidago leaves (a) and stems (b)

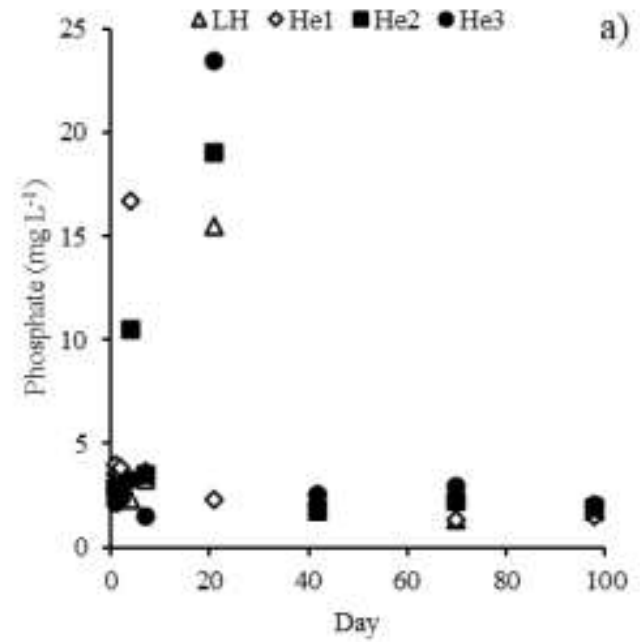

\section{CONCLUSIONS}

In this study decomposition processes of Solidago virgaurea litter under aquatic environment were analyzed. The $\mathrm{pH}$, conductivity, ammonium, and phosphate measurements were included in the observation. In conclusion, this study showed that Solidago virgaurea could leach significant concentrations of nutrients when desiccated and rewetted. The water quality $(\mathrm{pH}$, conductivity, ammonium, and phosphate concentrations) of Lake Hévíz and Hévíz canal were impacted by the

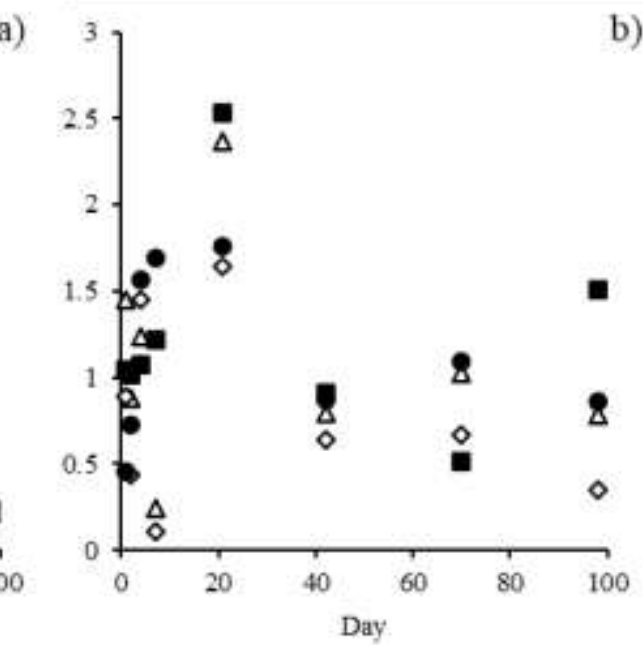

decomposition of the Solidago virgaurea in winter season as well.

\section{ACKNOWLEDGEMENTS}

The publication is supported by the EFOP-3.6.3VEKOP-16-2017-00008 project. The project is cofinanced by the European Union and the European Social Fund.

„Supported by the ÚNKP-20-3-1 New National Excellence Program of the Ministry for Innovation And Technology From The Source of the National Research, Development and Innovation Fund."

\section{REFERENCES}

Arsuffi, T.L.- Suberkropp, K. (1984): Leaf processing capabilities of aquatic hyphomycetes: interspecific differences and influence on shredder feeding preferences. Oikos, 42, pp. 144-154.

Bärlocher, F.-Gessner, M.O.-Graca M.A.S. (2007): Litter dynamics. Methods to Study Litter Decomposition A Practical Guide. Springer: Dordrecht, The Netherlands.
Bärlocher, F.-Tibbo, P.G.-Christie, S.H. (1989): Formation of phenol-protein complexes and their use by two stream invertebrates. Hydrobiologia, 173, pp. 243-249.

Bärlocher, F. (1992): Effects of drying and freezing autumn leaves $f$ on leaching and colonization by aquatic hyphomycetes. Freshwater Biology, 28, pp. 1-7. 
Bengtsson, G. (1992): Interactions between fungi, bacteria and beech leaves in a streammicrocosm. Oecologia, 89, pp. 542-549.

Berg, B.-McClaugherty, C. (2008): Overview of Plant Litter decomposition. Plant Litter: Decomposition, Humus Formation, Carbon Sequestration. Springer: Verlag Berlin Heidelberg. Chapter 1, Introduction 1.

Cornelissen, J.H.C.-Perez-Harguindeguy, N.-Diaz, S.-Grime, J.P.Marzano, B.-Cabido, M.-Vendramini, F.-Cerabolini, B. (1999): Leaf structure and defence control litter decomposition rate across $\mathrm{f}$ species and life forms in regional floras on two continents. New Phytologist, 143, pp. 191-200.

Dahrouga, Z. -Santana, N.F.-Pagioro, T.A. (2016): Eichhornia azurea decomposition and the bacterial dynamic: an experimental research. Brazilian Journal of Microbiology. 47, pp. 279-286.

Enríquez, S.-Duarte, M.-Sand-Jensen, K. (1993): Patterns in decomposition rates among photosynthetic organisms: the importance of detritus C:N:P content. Oecologia, 94, pp. 457471.

Esteves, F.A. (1988): Fundamentos da Limnologia. Rio de Janeiro:Interciência/FINEP, Rio de Janeiro.

Gessner, M.O.-Dobson, M. (1993): Colonization of fresh andd ried leaf-litter by lotic macroinvertebrates. Archiv für Hydrobiologie, 127, pp. 141-149.

Gessner, M.O.-Suberkropp, K.-Chauvet, E. (1997): Decomposition of plant litter in marine and freshwater ecosystems. In D.T. Wicklow \& B. Söderström (eds.). The Mycota, Vol. IV: Environmental and Microbial Relationships. Springer-Verlag, Berlin.

Gessner, M.O. (1991): Differences in processing dynamics of fresh and dried leaf litter in a stream ecosystem. Freshwater Biology, 26, pp. 387-398.

Gibtan, A.-Abera, L. (2012): Assessment of the major threats and challenges of Lake Ziway wetland systems, Ethiopia. In: Wetlands for sustainable development and climate change mitigation, p: 147-163, 1st Proceeding of Blue Nile Water Institute, Jan 25-27, 2011, Bahir Dar, Ethiopia, pp. 240.
Kołodziej, B.-Kowalski, R.-Kedzia, B. (2011): Antibacterial and antimutagenic activity of extracts aboveground parts of three Solidago species: Solidago virgaurea L., Solidago canadensis L. and Solidago gigantea Ait. Journal of Medicinal Plants Research, 5, pp. 6770-6779.

Park, S.-Cho, K. (2003): Nutrient Leaching from Leaf Litter of Emergent Macrophyte (Zizania latifolia) and the Effects of Water Temperature on the Leaching Process. Korean Journal of Biological Science. 7, pp. 289-294.

Pennings, S.C.-Paul, V.J. (1992): Effect of plant toughness, calcification, and chemistry on hervibory by Dolabella auricularia. Ecology, 73, pp. 1606-1619.

Pomogyi, P. (1983): A Kis-Balatoni tömegesen előforduló hínárfajok tápanyagforgalma és annak kapcsolata a vízminőségvédelemmel. Kandidátusi értékezés. Keszthely.

Reddy, K.R.-Sacco, P.D. (1981): Decomposition of water hyacinth in agricultural drainage water. Journal of Environmental Quality. 10, pp. 228-234.

Richardson, D.M. (2011): Fifty Years of Invasion Ecology: the Legacy of Charles Elton. Wiley-Blackwell.

Semple, J.C.-Cook, R.E. (2006): 163. Solidago Linnaeus, Sp. Flora of North America, 20, pp. 3, 12, 14-15, 18-19, 97, 102, 105107.

Suberkropp, K.-Klug, M. (1976): Fungi and bacteria associated with leaves during processing in a woodland stream. Ecology pp. 57, 707-719.

Tamire, G.--Mengistou, S.-Degefe, G. (2017): Decomposition rates and nutrient leaching efficacy of the dominant macrophytes in Lake Ziway, Ethiopia. International Journal of Aquatic Science. 8. 2, pp. 96-106.

Wu, S.-He, S.-Zhou, W-Gu, J.-Huang, J.-Gao, L.-Zhang, X. (2017): Decomposition characteristics of three different kinds of aquatic macrophytes and their potential application as carbon resource in constructed wetland. Environmental Pollution. 231, pp. 1122-1133. 
